\title{
NITROGEN FERTIGATION TO IMPROVE NITROGEN USE EFFICIENCY AND CRUDE PROTEIN ON SILAGE CORN
}

\author{
Ramazan YOLCU $U^{1}$ and Oner CETIN ${ }^{2 *}$ \\ ${ }^{1}$ Regional Directorate of State Hydraulic Works, Diyarbakir, TURKEY \\ ${ }^{2}$ Dicle University, Faculty of Agriculture, Department of Agricultural Structures and Irrigation, \\ Diyarbakir, TURKEY \\ *Corresponding author: onercetin@dicle.edu.tr
}

Received: 29.05.2015

\begin{abstract}
This study investigated the effect of nitrogen $(\mathrm{N})$ fertigation frequency and different amounts of irrigation water on drip-irrigated silage corn. Experiments were conducted in the Southeastern Anatolia region of Turkey in 2011 and 2012. A split-plot experimental design was applied. The main plots contained four different rates of evaporation from Class $A$ pan $(E p): I_{1}, 50 \%, I_{2}, 75 \%, I_{3}, 100 \%$, and $I_{4}, 125 \%$. Sub-plots were designed with different frequencies of $N$ fertigation as follows: $N_{1}$ : application of two-fifths of the total $N$ when the plant height became about $50-60 \mathrm{~cm}$, and the last two-fifths of it when the plants entered the stage of tasseling, $\mathrm{N}_{2}$ : application of $\mathrm{N}$ applied at each 2 irrigation cycles for 10 days, and $\mathrm{N}_{3}$ : application of $\mathrm{N}$ applied at each irrigation cycle for 5 days. One-fifth of the total $N$ was applied to the soil at sowing in all treatment regimes. The dry matter biomass $(D M)$ of $30 \mathrm{t} \mathrm{ha}^{-1}$ and total crude protein yield of $2.0 \mathrm{t} \mathrm{ha} \mathrm{t}^{-1}$ were obtained with $\mathrm{N}$ application of equal amounts at each irrigation cycle (5 days) and irrigation water consisting of $100 \%$ cumulative evaporation from Class A pan (Ep) for an optimum and appropriate treatment. Nitrogen use efficiency (NUE) and irrigation water use efficiency (IWUE) were $107.7 \mathrm{~kg} \mathrm{DM} \mathrm{ha}^{-1} \mathrm{~N}$ and $58.0 \mathrm{~kg} \mathrm{ha}^{-1} \mathrm{~mm}^{-1}$ $\left(5.8 \mathrm{~kg} \mathrm{~m}^{-3}\right)$, respectively. The requirement of the average value of irrigation water and the optimum wetted area ratio for drip-irrigated silage corn were $447 \mathrm{~mm}$ and 0.65 , respectively.
\end{abstract}

Key words: dry matter, fertigation, nitrogen use efficiency, protein, silage corn

\section{INTRODUCTION}

Corn (Zea mays L.) is the most important silage plant in the world because of its high yield, its high energy forage, and the fact that it is produced with less labor and machinery requirements than other forage crops. Many environmental, cultural and genetic factors influence corn forage yield and quality. Concentrated feed requirements decrease by $33-50 \%$ in animals fed with silage corn (Turgut, 2002; Sade and Soylu, 2008; Carpici et al., 2010).

Silage corn is used for feeding all dairy cattle on the farm, including growing animals, dry cows, and lactating cows. It must be supplemented with protein, minerals, and sometimes energy to meet the animal's nutrient requirements (Allen et al., 1995). It contains approximately 10.5-11.5 megajoules of metabolisable energy (MJME) $\mathrm{kg}^{-1}$ dry matter (DM) of energy and 7-9 $\%$ of crude protein (Kolver et al., 2001). The quality, yield, and profit of silage corn depend on the proper hybrid selection, the planting date, the plant density, the soil fertility, and pest control, irrigation and nutrition.
Corn is grown under irrigated conditions and, therefore, requires higher amounts of irrigation water compared to the other field crops (Musick et al., 1990; Cetin, 1996). In addition, it removes more N, phosphorus (P) and potassium (K) from the soil.

Arranging precise irrigation programs and using more effective irrigation methods are the best ways to increase yield while decreasing the amount of irrigation water used in agriculture (Karasahin, 2014). Thus, the correct amount of water used for silage corn is essential for producing high yields. Thus, proper irrigation management minimizes yield loss due to crop water stress, optimizes yield per unit of water applied and promotes good management practices.

The planting area and total silage production are about 17640 ha and 698956 tonnes in the region, respectively (TUIK, 2013). Recently, the growing of corn has increased in the GAP (Southeastern Anatolia Project) region of Turkey where the area featured in this study is located. This is because the climatic conditions are convenient for its growth. The water requirements of second crop corn in this region range from $800 \mathrm{~mm}$ through $1000 \mathrm{~mm}$ depending on irrigation scheduling for 
the surface irrigation (Cetin, 1996). However, drip irrigation enables the saving of water compared with furrow irrigation (Yazar et al., 2002). In addition, the government in Turkey has subsidized farmers who want to use a drip or sprinkler irrigation system, which has considerably increased the number of farmers using this method for their corn. Drip irrigation saves about 30-50\% more irrigation water than the irrigation in this region (Yazar et al., 2002; Cetin et al., 2013). Furthermore, many researchers reported that the saving of water and higher crop yields could be obtained if drip irrigation was used (Humphreys et al., 2005; Oktem, 2008; Payero et al., 2009; Kiziloglu et al., 2009).

On the other hand, water and nitrogen $(\mathrm{N})$ are the main limiting factors affecting agricultural production in arid and semiarid regions. Therefore, improving the efficiency of these inputs is the target for improved management (Morrow and Krieg, 1990; Bronson et al., 2006). The optimum $\mathrm{N}$ application rate was a function of irrigation depth. Ibrikci et al. (2001) reported that there were no differences among the $\mathrm{N}$ dosages more than the rate of $240 \mathrm{~kg} \mathrm{~N} \mathrm{ha}^{-1}$ in terms of yield for the second crop corn. Silage yield linearly increased up to rate of $240 \mathrm{~kg} \mathrm{~N} \mathrm{ha}^{-1}$ (Kara et al., 1999). A deficit irrigation level of 0.85ET (evapotranspiration) with an optimum total $\mathrm{N}$ of $225 \mathrm{~kg} \mathrm{~N}$ $\mathrm{ha}^{-1}$, including initial soil $\mathrm{N}$ and fertilizer, resulted in the highest amount of aboveground biomass for silage (Gheysari et al., 2009).

Fertigation, a modern agricultural technique, provides an excellent opportunity to maximize yield and minimize environmental pollution (Hagin et al., 2002) by increasing fertilizer use efficiency, minimizing fertilizer application and increasing return on the fertilizer invested (Cetin and Tolay, 2009; Kafkafi and Tarchitzky, 2011). Fertigation combines two main inputs required for plant growth and development: water and nutrients. The right combination of water and nutrients is the key to a high yield and a quality yield (Qasim et al., 2008).

Thus, silage corn producers require more information on how nitrogen fertigation and the amount of irrigation water affects forage quality and the yield of dry matter. The goal of this study was to improve $\mathrm{N}$ fertigation and to determine the response to different amounts of irrigation water on silage corn.

\section{MATERIALS AND METHODS}

\section{Experimental site}

This study was conducted over a two-year period at the lands of Devegecidi Dam (Diyarbakir, Turkey) during the 2011 and 2012 growing seasons. The site is located at $37^{\circ} 54^{\prime} \mathrm{N}, 40^{\circ} 14^{\prime} \mathrm{E}$, at an elevation of $748 \mathrm{~m}$ above sea level. The site shows typical terrestrial climatological properties. The average annual rainfall of $487 \mathrm{~mm}$ is concentrated during all months with the exception of the summer season. The average annual and daily maximum Class A pan evaporation values are 976 and $8.4 \mathrm{~mm}$, respectively. During the experimental years, average temperatures, relative humidity, wind speed and rainfall are 29.2-29.5 ${ }^{\circ} \mathrm{C}, 20.9-24.9 \%, 3.3-3.4 \mathrm{~m} \mathrm{sec}^{-1}$ and 3.4-9.8 $\mathrm{mm}$, respectively.

The soil texture at this site is clay. The soil consisted of $16 \%$ sand, $21 \%$ silt, and $63 \%$ clay in the upper soil profile. The bulk density ranged from 1.36 to $1.40 \mathrm{~g} \mathrm{~cm}^{-3}$ in the soil profile (Table 1).

The infiltration rate was $9 \mathrm{~mm} \mathrm{~h}^{-1}$. There were no risks associated with the water table or soil salinity. Additional physical and chemical properties of the experimental site are given in Table 1.

Table 1. Some physical and chemical properties of soil in the experimental site

\begin{tabular}{|c|c|c|c|c|c|c|c|c|c|c|c|c|c|}
\hline \multirow[b]{2}{*}{$\begin{array}{c}\text { Soil } \\
\text { depth } \\
(\mathbf{c m})\end{array}$} & \multirow[b]{2}{*}{ pH } & \multirow[b]{2}{*}{$\begin{array}{c}\mathbf{P}_{2} \mathbf{O}_{5} \\
(\mathbf{p p m})\end{array}$} & \multirow[b]{2}{*}{$\begin{array}{c}\text { Org. } \\
\text { mat. } \\
(\%)\end{array}$} & \multirow[b]{2}{*}{$\begin{array}{c}\text { Lime } \\
(\%)\end{array}$} & \multirow[b]{2}{*}{$\begin{array}{c}\text { EC } \\
(\mathrm{dS} / \mathrm{m})\end{array}$} & \multicolumn{4}{|c|}{ Soil texture } & \multirow[b]{2}{*}{$\begin{array}{c}\text { F.C. } \\
\text { (g } 100 \\
\text { g) }\end{array}$} & \multirow[b]{2}{*}{$\begin{array}{l}\text { W.P. } \\
(\text { g 100-1 } \\
\text { g) }\end{array}$} & \multirow[b]{2}{*}{$\begin{array}{c}\text { Bulk } \\
\text { density } \\
\left(\mathrm{g} / \mathrm{cm}^{3}\right)\end{array}$} & \multirow{2}{*}{$\begin{array}{c}\text { Inf. } \\
\text { rate } \\
\left(\mathrm{mm}_{1} \mathrm{~h}\right.\end{array}$} \\
\hline & & & & & & $\begin{array}{c}\text { Sand } \\
(\%)\end{array}$ & $\begin{array}{l}\text { Silt } \\
(\%)\end{array}$ & $\begin{array}{c}\text { Clay } \\
(\%)\end{array}$ & $\begin{array}{l}\text { Text. } \\
\text { class }\end{array}$ & & & & \\
\hline $0-30$ & 7.8 & 18.4 & 2.3 & 11.3 & 1.0 & 16 & 21 & 63 & $\mathrm{C}$ & 34.7 & 23.1 & 1.36 & \\
\hline $30-60$ & 7.7 & -- & 1.9 & 9.4 & 1.0 & 16 & 25 & 59 & $\mathrm{C}$ & 33.5 & 22.2 & 1.39 & 9 \\
\hline $60-90$ & 7.8 & -- & 1.1 & 9.4 & 1.1 & 5 & 30 & 55 & $\mathrm{C}$ & 34.1 & 23.6 & 1.40 & \\
\hline
\end{tabular}

\section{Treatments and Irrigation Scheduling}

The study was carried out using randomized blocks with split plots and three replications. The main plots had different irrigation levels with sub-plots in which $\mathrm{N}$ fertigation was applied at various frequencies. The treatments are given in Table 2.

$$
\text { Plot area, A: } 4.20 \times 8.00 \mathrm{~m}=33.60 \mathrm{~m}^{2}
$$

One-fifth of the total $\mathrm{N}$ and $\mathrm{P}$ were added to the soil at sowing (Burt, 1998; Hartz and Hochmuth, 2005; Cetin and Tolay, 2009). The remaining $\mathrm{N}$ and $\mathrm{P}$ were applied by means of fertigation according to the treatment regimen. For treatment $\mathrm{N}_{1}$, the remaining $\mathrm{N}$ was applied as twofifths of the total $\mathrm{N}$ when the plant height became about
50-60 cm, the last two-fifths when the plants entered the stage of tasseling. For treatment $\mathrm{N}_{2}$ and $\mathrm{N}_{3}$, the remaining $\mathrm{N}$ was divided equally according to the total number of irrigation cycles depending on irrigation treatments.

The irrigation schedule was, thus, applied based on class A pan evaporation. The irrigation interval was 5 days.

The amount of irrigation water was calculated using the formula (Cetin and Bilgel, 2002)

$$
\mathrm{I}=\mathrm{A} \cdot \mathrm{Ep} \cdot \mathrm{K} \cdot \mathrm{P}
$$

Where I is the amount of irrigation water applied (L), $A$ is the area of the plot $\left(\mathrm{m}^{2}\right)$, Ep is the cumulative amount 
of Class A pan evaporation for every 5 days (mm), K relates to the different percentages based on the amount of irrigation water for the Class $\mathrm{A}$ pan, and $\mathrm{P}$ is the wetted area. The $\mathrm{P}$ was assumed and used as 0.65 .

Table 2. The treatments in the experiments

\begin{tabular}{lr}
$\begin{array}{l}\text { Main Plots } \\
\text { (Irrigation levels) }\end{array}$ & $\begin{array}{c}\text { Sub-plots } \\
\text { (Nitrogen fertigation frequency) }\end{array}$ \\
\hline $\begin{array}{l}\mathrm{I}_{1(0.50)}: 50 \% \text { of amount of } \\
\text { cumulative evaporation from Class }\end{array}$ & $\mathrm{N}_{1}: \begin{array}{l}\text { Application of one-fifth of the total at sowing date, two-fifth of the total } \mathrm{N} \\
\text { when the plant hight became about } 50-60 \mathrm{~cm} \text {, last two-fifth of it when the } \\
\text { plants became the stage of tasseling }\end{array}$ \\
$\mathrm{I}_{2(0.75):}$ p $75 \%$ of Ep & $\mathrm{N}_{2}: \begin{array}{l}\text { Application of one-fifth of the total at sowing date, the remaining } \mathrm{N} \text { was } \\
\text { applied at each } 2 \text { irrigation cycles for } 10 \text { days }\end{array}$ \\
$\mathrm{I}_{3(1.00)}: 100 \%$ of Ep & $\mathrm{N}_{3}: \begin{array}{l}\text { Application of one-fifth of the total at sowing date, the remaining } \mathrm{N} \text { was } \\
\text { applied at each irrigation cycle for } 5 \text { day }\end{array}$ \\
$\mathrm{I}_{4(1.25)}: 125 \%$ of Ep &
\end{tabular}

The first irrigation was applied to provide homogenous emergence by sprinkler irrigation after sowing. The amount of irrigation water applied was $60 \mathrm{~mm}$ for this. At the first drip irrigation, irrigation water was applied until it reached the field capacity for the soil depth of $0-60 \mathrm{~cm}$ for all treatments. After reaching field capacity, the irrigation program was started depending on the irrigation treatments described above. The final irrigation was applied at the dough stage, approximately a week before harvest.

The soil samples in the plots were taken to determine the gravimetric soil-water content (Smith and Warrick, 2007). Three samples were taken per plot at depths of 0$30,30-60$, and $60-90 \mathrm{~cm}$. The samples were collected 1 day before irrigation.

\section{Irrigation System and Design}

The lateral lines had on-line compensating emitters; the discharge rate of the emitters was $4 \mathrm{~L} \mathrm{~h}^{-1}$ at an operating pressure of $100 \mathrm{kPa}$. An emitter spacing of 0.40 $\mathrm{m}$ was chosen due to the soil characteristics (Yildirim, 2003). The plant row spacing and plant spacing were 0.70 and $0.15 \mathrm{~m}$, respectively. Lateral lines were laid out along two corn plant rows. The drip system consisted of polyethylene (PE) laterals, $16 \mathrm{~mm}$ in diameter. Each plot had a PE manifold pipeline of $40 \mathrm{~mm}$ in diameter. The irrigation water, which was pumped from a dam reservoir, was conveyed by means of PE pipes $50 \mathrm{~mm}$ in diameter into the manifolds along the border of the plots. In addition, the system control unit had a vortex sand separator, sand media filters, a fertilizer tank, screen mesh filters, and pressure gauges. The water flow was measured with a mechanical water meter for each plot.

\section{Agricultural Applications}

Corn seeds (Zea mays cv. Dekalb, C-955) were sown on 25 June in both years. Hoeing was done twice at the beginning of the developing stage of the plants. The plots were treated with recommended insecticides against corn worms and aphids. Thus, there were no other serious health problems in terms of plants and fruits. The harvest was carried out at the dough stage of the plants in the last week of September.

With the exception of pre-plant fertilizing, all the fertilizer was applied by fertigation. All fertilizer were applied the appropriate amount $\left(\mathrm{N}: 240\right.$ and $\mathrm{P}_{2} \mathrm{O}_{5}: 100 \mathrm{~kg}$ $\mathrm{ha}^{-1}$ ) recommended by Kara et al. (1999) and Ibrikci et al. (2001) for second crop silage corn.

\section{Nitrogen Application Frequency}

Before the sowing, all the plots were fertilized with $\mathrm{N}$ of $48 \mathrm{~kg} \mathrm{ha}^{-1}, \mathrm{P}_{2} \mathrm{O}_{5}$ of $20 \mathrm{~kg} \mathrm{ha}^{-1}$ as a basal fertilizer. This means that one-fifth of the total $\mathrm{N}$ and $\mathrm{P}$ were added to the soil at sowing. $\mathrm{N}$ fertigation was applied in blocks. Fertigation was started at the first irrigation cycle and continued through the plants' tasseling stage. The fertilizer used for fertigation was a blend that included $\mathrm{N}$, $\mathrm{P}$, and potassium $(\mathrm{K})$ at $19-5-5$.

For fertigation, a pressure differential was created by throttling the water flow in the control head and diverting a fraction of the water through a tank containing the fertilizer solution (Sne, 2006).

\section{Dry Matter (DM)}

For the original fresh yield data, all the plants in the plots were cut from above ground except $1.0 \mathrm{~m}$ of the beginning and end of the plot and 1 row at the side of the plots. Above-ground biomass (i.e., fresh yield), were, thus, measured based on the plot area.

For the DM, 10 plants were randomly selected to represent all the plants harvested and were then broke into pieces. The plant samples were put in an oven set $65{ }^{\circ} \mathrm{C}$ for 24 hours (Kacar, 1984). DM was calculated as the dried plant samples were divided into original fresh plants yields. This value calculated as a percentage, was used to convert the fresh silage corn yield to DM based on the unit area (Sade, 1987).

\section{Plant Analysis}

Plant samples taken from 10 plants representing the whole plot were dried in an oven at $65^{\circ} \mathrm{C}$. The dried plant 
samples were ground and analyzed for $\mathrm{N}$ content. The total $\mathrm{N}$ in the representing samples was determined according to the whole dried plant and was based on the method of Horneck and Miller (1998). In order to calculate the percentage of protein, the following equation was used (Tisdale et al., 1993).

$$
\% \text { Protein }=\% \mathrm{~N} \times 6.25
$$

In order to calculate total crude protein yield, the percentage protein was multiplied by the total DM yield.

\section{Irrigation water use efficiency}

Irrigation water use efficiency (IWUE, $\mathrm{kg} \mathrm{ha}^{-1} \mathrm{~mm}^{-1}$ and/or $\mathrm{kg} \mathrm{m}^{-3}$ ) was calculated as dry matter (DM) yield $(\mathrm{kg})$ obtained per unit depth and/or volume of irrigation water applied ( $\mathrm{mm}$ and/or $\mathrm{m}^{3}$ ) (Howell, 2006).

\section{Nitrogen Use Efficiency (NUE)}

The NUE for the fertigation treatments was calculated as the ratio of DM yield $\left(\mathrm{kg} \mathrm{ha}^{-1}\right)$ to the amount of $\mathrm{N}(\mathrm{kg}$ $\mathrm{ha}^{-1}$ ) applied for all the nitrogen frequencies (Moll et al., 1982; Witt et al., 1999).

\section{Statistical Analysis and Evaluation}

For statistical analysis, randomized blocks in split plots with three replications were used to evaluate the effects of the treatments on DM yield and other parameters. The data were analyzed using an ANOVA.
Variance analyses were performed for each experimental year. In addition, Duncan's multiple test, an acceptable tool for the comparison of discrete data, was used to compare different treatments (Yurtsever, 2011).

\section{RESULTS AND DISCUSSION}

\section{Total Fresh and DM Yield}

The total fresh and dry matter (DM) yields of silage corn according to the experimental years are given in Table 3. It is evident that the total fresh and DM yield varied widely from 53.1 to 93.3 and 14.8 to $33.9 \mathrm{t} \mathrm{ha}^{-1}$ depending on the treatment and experimental years, respectively. Significant $(* * \mathrm{P}<0.01)$ effects of different irrigation levels and $\mathrm{N}$ fertigation frequencies on both fresh and DM yields were found separately in both experimental years. This means that there were no interactions between the amount of irrigation water applied and different fertigation frequencies of $\mathrm{N}$. Thus, the data in the main plots and subplots on the yields were derived separately from the original data in experimental plots in Table 3 to analyze the effects of the treatments. Thus, the data in Table 4 were obtained.

In general, the fresh yields in both 2011 and 2012 increased significantly depending on increasing amounts of irrigation water and $\mathrm{N}$ fertigation frequencies (Table 3 and 4)

Table 3. Fresh and dry matter yields according to the experimental years for main and sub-plot treatments.

\begin{tabular}{|c|c|c|c|c|c|c|c|}
\hline \multirow{2}{*}{ Irrigation levels } & \multirow{2}{*}{ Nitrogen fertigation frequency } & \multicolumn{3}{|c|}{ Fresh biomass (t ha $\left.{ }^{-1}\right)$} & \multicolumn{3}{|c|}{ Dry matter $\left(\mathrm{t} \mathrm{ha}^{-1}\right)$} \\
\hline & & 2011 & 2012 & Mean & 2011 & 2012 & Mean \\
\hline \multirow{3}{*}{$\mathrm{I}_{1(0.50)}$} & $\mathrm{N}_{1}$ & 53.1 & 54.8 & 54.0 & 14.8 & 16.7 & 15.7 \\
\hline & $\mathrm{N}_{2}$ & 58.1 & 58.8 & 58.5 & 16.4 & 17.3 & 16.8 \\
\hline & $\mathrm{N}_{3}$ & 56.2 & 60.9 & 58.6 & 16.7 & 19.0 & 17.8 \\
\hline \multirow{3}{*}{$\mathrm{I}_{2(0.75)}$} & $\mathrm{N}_{1}$ & 62.0 & 66.1 & 64.1 & 19.1 & 21.4 & 20.2 \\
\hline & $\mathrm{N}_{2}$ & 63.2 & 69.1 & 66.2 & 19.4 & 22.9 & 21.2 \\
\hline & $\mathrm{N}_{3}$ & 72.1 & 71.5 & 71.8 & 21.9 & 24.0 & 22.9 \\
\hline \multirow{3}{*}{$\mathrm{I}_{3(1.00)}$} & $\mathrm{N}_{1}$ & 68.4 & 70.3 & 69.4 & 22.4 & 23.9 & 23.2 \\
\hline & $\mathrm{N}_{2}$ & 70.1 & 77.6 & 73.9 & 23.1 & 26.4 & 24.8 \\
\hline & $\mathrm{N}_{3}$ & 85.1 & 90.6 & 87.9 & 28.3 & 31.4 & 30.0 \\
\hline \multirow{3}{*}{$\mathrm{I}_{4(1.25)}$} & $\mathrm{N}_{1}$ & 73.9 & 78.4 & 76.2 & 25.7 & 28.5 & 27.1 \\
\hline & $\mathrm{N}_{2}$ & 79.6 & 86.0 & 82.8 & 27.6 & 31.3 & 29.4 \\
\hline & $\mathrm{N}_{3}$ & 86.0 & 93.3 & 89.7 & 30.7 & 33.9 & 32.3 \\
\hline
\end{tabular}

Table 4. The DM yields derived separately depending on amount of irrigation water applied and nitrogen fertigation frequency

\begin{tabular}{|c|c|c|c|c|c|c|c|}
\hline \multirow[b]{2}{*}{$\begin{array}{l}\text { Irrigation } \\
\text { levels }\end{array}$} & \multicolumn{2}{|c|}{2011} & \multicolumn{2}{|c|}{2012} & \multirow[b]{2}{*}{$\begin{array}{l}\text { Nitrogen fertigation } \\
\text { frequency }\end{array}$} & \multirow{2}{*}{$\begin{array}{c}2011 \\
\begin{array}{c}\text { DM yield } \\
\left(\mathrm{t} \mathrm{ha} \mathbf{~ h}^{-1}\right)\end{array}\end{array}$} & \multirow{2}{*}{$\begin{array}{c}2012 \\
\text { DM yield } \\
\left(\mathrm{t} \mathrm{ha}^{-1}\right)\end{array}$} \\
\hline & $\begin{array}{c}\text { IW } \\
(\mathbf{m m})\end{array}$ & $\begin{array}{c}\text { DM yield } \\
\left(\mathrm{t} \mathrm{ha}^{-1}\right)\end{array}$ & $\begin{array}{c}\text { IW } \\
(\mathbf{m m})\end{array}$ & $\begin{array}{l}\text { DM yield } \\
\left(\mathrm{t} \mathrm{ha}^{-1}\right)\end{array}$ & & & \\
\hline $\mathrm{I}_{1(0.50)}$ & 278 & $16,0 \mathrm{~d}^{1}$ & 292 & $17,6 \mathrm{c}$ & $\mathrm{N}_{1}$ & $20,5 \mathrm{~b}$ & $22,6 \mathrm{c}$ \\
\hline $\mathrm{I}_{2(0.75)}$ & 357 & $20,1 \mathrm{c}$ & 376 & $22,7 \mathrm{~b}$ & $\mathrm{~N}_{2}$ & $21,6 \mathrm{~b}$ & $24,4 \mathrm{~b}$ \\
\hline $\mathrm{I}_{3(1.00)}$ & 435 & $24,6 \mathrm{~b}$ & 459 & $27,2 \mathrm{a}$ & $\mathrm{N}_{3}$ & $24,4 \mathrm{a}$ & $27,1 \mathrm{a}$ \\
\hline $\mathrm{I}_{4(1.25)}$ & 514 & $28,0 \mathrm{a}$ & 543 & $31,2 \mathrm{a}$ & & & \\
\hline
\end{tabular}

DM: Dry matter

1: The same letters are not significantly different $(* * \mathrm{P}<0.01)$ according to a Duncan's multiple range test 
DMs varied from 27.9 to $36.4 \%$ basis on fresh biomass yield depending on the experimental years and treatments. Garcia (2011) reported that high quality maize silage contains 30-35\% DM. Accordingly, the results from our study were considerably appropriate for silage fodder.

In 2011, the highest DM yield varied from 16.0 to 28.0 $\mathrm{t} \mathrm{ha}^{-1}$ depending on the amount of irrigation water applied. The maximum yield $\left(28.0 \mathrm{t} \mathrm{ha}^{-1}\right)$ was obtained with treatment $\mathrm{I}_{4}$ in which $125 \%$ of Ep was applied as irrigation water and this was significantly higher compared to the other treatments. Under the irrigation treatment $\mathrm{I}_{4}(125 \%$ Ep), the amount of irrigation water applied was $514 \mathrm{~mm}$.

In 2012, the highest DM yield varied from 17.6 to 31.2 $\mathrm{t} \mathrm{ha}^{-1}$ also depending on the amount of irrigation water applied. There were no significant differences between treatment $I_{3}$ and treatment $I_{4}$ in this experimental year. Under the irrigation treatment $\mathrm{I}_{3}(100 \% \mathrm{Ep})$ and treatment $\mathrm{I}_{4}(125 \% \mathrm{Ep})$ the amount of irrigation water applied was 459 and $543 \mathrm{~mm}$, respectively. On the other hand, there were approximately similar effects of the treatments on the DM yields in the experimental years.

The applied irrigation water in the growing periods was approximately similar (Table 4). This can be attributed to the fact that there were no considerable differences in climatic conditions such as pan evaporation, relative humidity, and wind speed during the growing period. The results obtained during the two years show that DM yield is significantly $(* * \mathrm{P}<0.01)$ affected by increasing water and that the highest values were obtained under treatment $I_{3}\left(100 \%\right.$ Ep) and treatment $I_{4}(125 \%$ Ep). Increasing amounts of water resulted in increased DM yield. There were, thus, significant linear relationships $\left(y=0.052 x+1.77, r^{2}=0.99 * *\right.$ for 2011 and $\mathrm{y}=0.054 \mathrm{x}+2.05, \mathrm{r}^{2}=0.99 * *$ for 2012) between applied irrigation water and DM yield (Fig. 1). Similar findings were put forward by Yazar et al. (2002); Oktem et al. (2003); Greenwood et al. (2008) and Bouazzama et al. (2012).

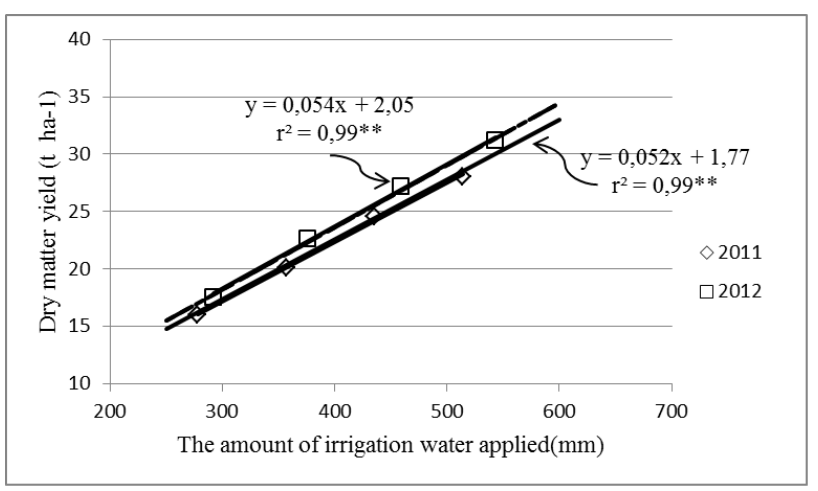

Fig. 1. Dry matter yield of corn silage versus the amount of irrigation water applied

As expected, the highest irrigation water (IW) occurred in $\mathrm{I}_{4}(125 \%$ Ep) obviously owing to an adequate and/or increased soil water supply during the growing period. Other irrigation strategies, especially $\mathrm{I}_{1}(50 \% \mathrm{Ep})$ and $\mathrm{I}_{2}\left(\begin{array}{lll}75 & \% & \mathrm{Ep}\end{array}\right)$ caused a certain water deficit and consequently a lower DM yield. DM accumulation was, thus, increased by irrigation (Schmaler et al., 2003; Bouazzama et al., 2012).

Oktem et al. (2003) reported similarly that the fresh ear yield was reduced as the amount of irrigation water decreased and 100\% of Ep would be optimal for sweet corn grown in semi-arid regions similar to the area where this work was conducted. They obtained also linear relationships between the amount of water applied and fresh ear yield.

On the other hand, a linear relationship has been reported between corn grain yield and evapotranspiration (Gencoglan and Yazar, 1999; Yazar et al., 2002; Cakir, 2004; Payero et al., 2006). Overman and Martin (2002) confirmed the linear relation between grain and silage yield response to irrigation for corn.

Considering the DM yields obtained in the different study areas, Emile et al. (2006) determined dry matter yield for irrigated maize as $20.1 \mathrm{t} \mathrm{ha}^{-1}$ in France. Greenwood et al. (2008) indicated that the dry matter yield of silage corn without water stress was $22 \mathrm{t} \mathrm{ha}^{-1}$. Bouazzama et al. (2012) reported that DM yields varied from $5.3 \mathrm{t} \mathrm{ha}^{-1}$ under the $40 \%$ ETc to $16.4 \mathrm{t} \mathrm{ha}^{-1}$ under $100 \%$ ETc. Cigdem and Uzum (2006) found that dry matter yield of full irrigated silage corn was 7.2-8.5 $\mathrm{t} \mathrm{ha}^{-1}$.

Comparing our findings to the data obtained in other study areas on silage corn DM yield, it was relatively higher than those. Our study area has a hot and dry summer climate with higher amounts of sunlight. The average and maximum temperatures during the growing season in which it was from June through September were ranged from 25.0 to $31.3{ }^{\circ} \mathrm{C}$ and 32.4 to $44.7{ }^{\circ} \mathrm{C}$, respectively. In addition sunlight duration ranged from 9.9 to 12.4 hours per day (DMI, 2014). Yields were, thus, positively associated with the accumulation of sunlight. This relationship was expected because the intensity and duration of sunlight influences the amount of photosynthesis (Duncan et al., 1977; Young and Smith, 1980; Nafziger, 2011). Warmer temperatures and increased sunshine early in the season lead to higher yields, whereas low yields are due to water stress and excessive heat during pollination and the grain-filling stages (Nafziger, 2011).

It can be assumed that, in a condition of more sunshine, with a relatively constant and/or closed capacity soil water content due to the fact that drip irrigation was used, a greater assimilation of products will be achieved. This means a higher plant height and more leaves per plant and total yield.

On the other hand, DM yields increased as long as $\mathrm{N}$ fertigation frequency increased (Fig. 2). This result showed that application of $\mathrm{N}$ as split at the right time and appropriate amount of $\mathrm{N}$ increased DM. This was achieved by means of an appropriate frequency (i.e. more frequency) of $\mathrm{N}$ fertigation. Similarly, Lui et al. (2013) reported that an increase in the fertigation splits and in the amount of $\mathrm{N}$ applied increased the $\mathrm{N}$ uptake of corn at the filling stage. Furthermore, the three fertigation splits 
throughout the season produced a significantly higher yield than the single fertigation early in the season. Three fertigation splits obtained a high production while reducing the risk of $\mathrm{N}$ leaching. Hassan et al. (2010) stated that the maximum green fodder yield $\left(91.3 \mathrm{t} \mathrm{ha}^{-1}\right)$ and DM yield $\left(8.90 \mathrm{t} \mathrm{ha}^{-1}\right)$ was achieved with fertigation compared to broadcast and side dressing on silage corn.

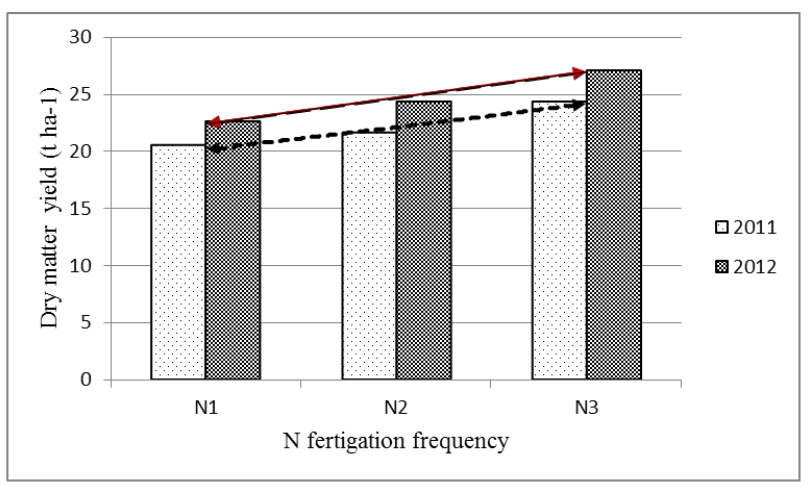

Fig. 2. Dry matter yield of corn silage versus nitrogen fertigation frequency

As a result, the corn can be seen to use nutrients when the plant grows most rapidly from about $45-50 \mathrm{~cm}$ high to grain fill. A split $\mathrm{N}$ application or applying $\mathrm{N}$ to the irrigation water are effective ways to minimize $\mathrm{N}$ loss by leading or denitrification (Garcia, 2011).

\section{Irrigation Water Use Efficiency (IWUE)}

IWUEs varied from 54.5 to $57.6 \mathrm{~kg} \mathrm{ha}^{-1} \mathrm{~mm}^{-1}$ (or 5.45 $5.76 \mathrm{~kg} \mathrm{~m}^{-3}$ ) in 2011 , and from 57.5 to $60.4 \mathrm{~kg} \mathrm{ha}^{-1} \mathrm{~mm}^{-1}$ (or $5.75-6.04 \mathrm{~kg} \mathrm{~m}^{-3}$ ) in 2012 depending on the treatments. There was no significant difference between treatments. However, decreasing amounts of irrigation water increased IWUE (Fig. 3). Similarly, Yazar et al. (2002) and Rusere et al. (2012) showed that a deficit in irrigation resulted in a significant decline in corn yield and an increase in IWUE. Additionally, Kang and Zhang (2004) reported that IWUE increased essentially by decreasing the amounts of the irrigation water. Yazar et al. (2009) reported that IWUE varied from $1.61 \mathrm{~kg} \mathrm{~m}^{-3}$ in full irrigation to $2.25 \mathrm{~kg} \mathrm{~m}^{-3}$ in some deficit irrigation treatments. In all the cases, IWUE values related to deficit irrigations were higher than those of full irrigation.

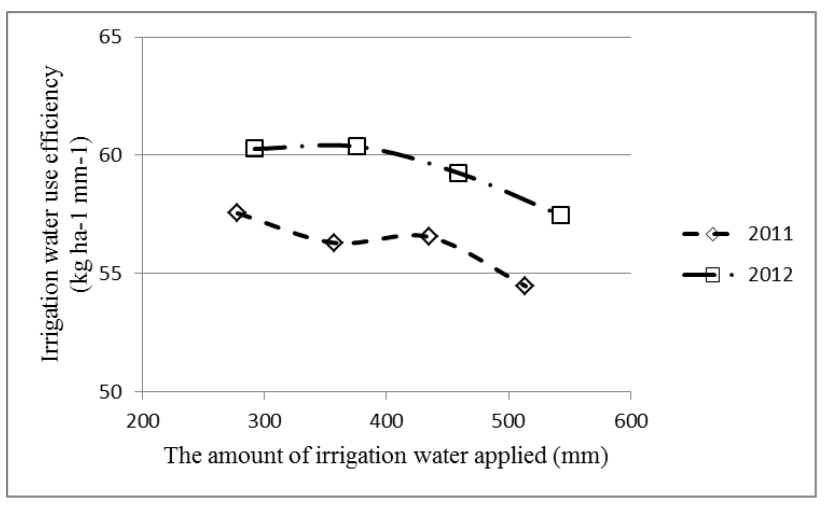

Fig. 3. Irrigation water use efficiency versus the amount of irrigation water applied

On the other hand, in the study carried out by Hammad et al. (2012) the highest IWUE achieved was 16.58 and $18.6 \mathrm{~kg} \mathrm{ha}^{-1} \mathrm{~mm}^{-1}$ by means of an application of $225 \mathrm{~kg} \mathrm{~N}$ $\mathrm{ha}^{-1}$ with an irrigation water depth of $525 \mathrm{~mm}$ during both growing seasons.

\section{Total Protein Yield}

The protein contents of silage corn ranged from 6.63 to $9.78 \%$ depending on the amount of irrigation water applied and $\mathrm{N}$ the fertigation frequency. The protein content decreased as long as the amount of irrigation water increased (Table 5). Similarly, Garcia (2011) reported that crude protein content was 7.2 and $5.2 \%$ for the severe deficit in irrigation and the full irrigation, respectively.

Total crude protein yield ranged widely from 1.54 to $2.19 \mathrm{t} \mathrm{ha}^{-1}$ depending on $\mathrm{N}$ fertigation and the amount of irrigation water applied (Table 5). Both fertigation frequency and the amount of irrigation water significantly affected $(\mathrm{P}<0.05)$ the crude protein content and total crude protein yield. The total protein yield increased as long as the $\mathrm{N}$ frequency and amount of irrigation water increased (Fig. 4).

Table 5. Protein content and total protein yield basis dry matter

\begin{tabular}{|c|c|c|c|c|c|c|c|c|c|}
\hline \multirow[b]{2}{*}{$\begin{array}{l}\text { Irrigation } \\
\text { levels }\end{array}$} & \multicolumn{2}{|c|}{2011} & \multicolumn{2}{|c|}{2012} & \multirow[b]{2}{*}{ NFF } & \multicolumn{2}{|c|}{2011} & \multicolumn{2}{|r|}{2012} \\
\hline & $\begin{array}{l}\text { PC } \\
(\%)\end{array}$ & $\begin{array}{c}\text { TPY (t } \\
\left.\text { ha }^{-1}\right)\end{array}$ & PC (\%) & $\begin{array}{c}\text { TPY } \\
\left(\begin{array}{c}t \\
\text { ha }\end{array}\right. \\
1)\end{array}$ & & $\begin{array}{l}\text { PC } \\
(\%)\end{array}$ & $\begin{array}{c}\text { TPY (t } \\
\left.\text { ha }^{-1}\right)\end{array}$ & $\begin{array}{l}\text { PC } \\
(\%)\end{array}$ & TPY $\left(\mathbf{t ~ h a}^{-1}\right)$ \\
\hline $\mathrm{I}_{1(0.50)}$ & 9.78 & $1,54 \mathrm{c}^{1}$ & 8.57 & 1,52 & $\mathrm{~N}_{1}$ & 8.80 & $1,77 \mathrm{~b}$ & 7.88 & 1,75 \\
\hline $\mathrm{I}_{2(0.75)}$ & 8.67 & $1,74 \mathrm{~b}$ & 7.87 & 1,78 & $\mathrm{~N}_{2}$ & 8.20 & $1,76 \mathrm{~b}$ & 7.73 & 1,84 \\
\hline $\mathrm{I}_{3(1.00)}$ & 8.07 & $1,98 \mathrm{a}$ & 7.50 & 2,03 & $\mathrm{~N}_{3}$ & 8.70 & $2,07 \mathrm{a}$ & 7.40 & 1,94 \\
\hline $\mathrm{I}_{4(1.25}$ & 7.80 & $2,19 \mathrm{a}$ & 6.63 & 2,06 & & & & & \\
\hline
\end{tabular}

PC: Protein content, TPY: Total protein yield, NFF: Nitrogen fertigation frequency

1: The same letters are not significantly different according to a Duncan's multiple range test 


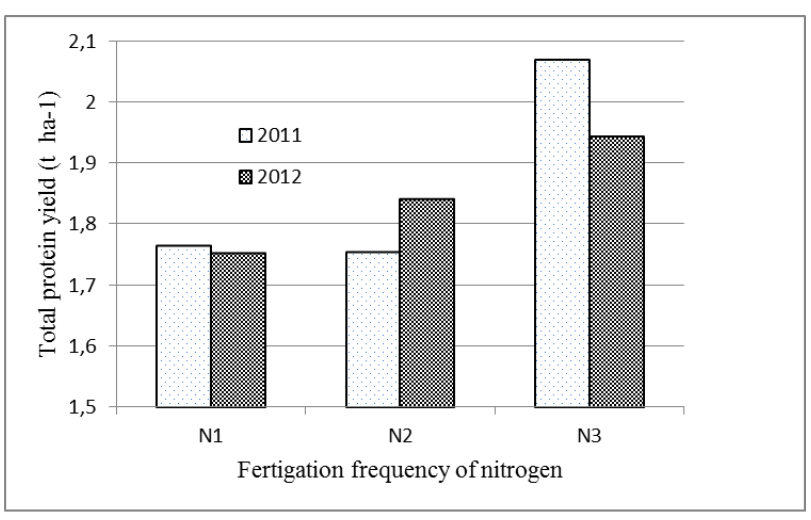

Fig. 4. Total protein yield versus nitrogen fertigation frequency

$$
\text { Nitrogen Use Efficiency (NUE) }
$$

The NUEs ranged from 66.5 to $130.0 \mathrm{~kg} \mathrm{DM} \mathrm{kg}^{-1} \mathrm{~N}$ depending on the experimental years and the treatments used. The maximum NUE was obtained for $\mathrm{N}$ fertigation every irrigation cycles (5 days) and for applications of 125 $\%$ Ep in both experimental years (Table 6).

Table 6. Nitrogen use efficiency according to the different irrigation and fertigation frequency basis on dry matter yield $(\mathrm{kg}$ DM kg-1 N ha-1)

\begin{tabular}{cccccc}
\hline Irri. Levels & $\mathbf{2 0 1 1}$ & $\mathbf{2 0 1 2}$ & NFF & $\mathbf{2 0 1 1}$ & $\mathbf{2 0 1 2}$ \\
\hline $\mathrm{I}_{1(0.50)}$ & 66,5 & 73,6 & $\mathrm{~N}_{1}$ & 85,4 & 94,3 \\
$\mathrm{I}_{2(0.75)}$ & 83,9 & 94,9 & $\mathrm{~N}_{2}$ & 90,1 & 101,9 \\
$\mathrm{I}_{3(1.00)}$ & 102,5 & 113,5 & $\mathrm{~N}_{3}$ & 101,7 & 112,8 \\
$\mathrm{I}_{4(1.25}$ & 116,7 & 130,0 & & & \\
\hline
\end{tabular}

In the previous studies, Hammad et al. (2012) stated that NUE was optimum at $75 \mathrm{~kg} \mathrm{ha}^{-1}$. Garcia (2011) reported that severely deficit irrigation resulted in $103 \mathrm{~kg}$ $\mathrm{DM} \mathrm{kg} \mathrm{N}^{-1} \mathrm{~N}$ and full irrigation resulted in $161 \mathrm{~kg} \mathrm{DM} \mathrm{kg}^{-1}$ $\mathrm{N}$. Compared to the previous studies, our findings in regard to NUE were appropriate for an optimum of corn silage growth. Thus, higher accumulations of $\mathrm{N}$ and $\mathrm{P}$ in grain improves yield and consequently leads to greater efficiency of these nutrients (Fageria et al., 2006). Better distribution of dry matter in crop plants is generally associated with higher yields, and consequently, a higher level of nutrient use efficiency (Fageria et al., 2008).

\section{CONCLUSIONS}

It can be concluded that, the optimum level of irrigation was $I_{3}(100 \%$ Class A pan evaporation). This can be derived from a consideration of the associated effects of the amount of irrigation water applied to the DM yield for both years. When calculating the amount of irrigation water for the drip-irrigated silage corn production, an optimum wetted area must be considered. In this study, an appropriate value was 0.65 . Thus, the requirement of irrigation water was $447 \mathrm{~mm}$ in average value. Similarly, the optimum nitrogen frequency was application of one-fifth of the total amount of $\mathrm{N}$ fertilizer at the sowing date, with the remaining $\mathrm{N}$ applied at each irrigation cycle for 5 days based on $240 \mathrm{~kg} \mathrm{ha}^{-1} \mathrm{~N}$. Using this irrigation schedule and $\mathrm{N}$ fertigation frequency, a DM yield of $30.0 \mathrm{t} \mathrm{ha}^{-1}$ and total crude protein of $2.0 \mathrm{t} \mathrm{ha}^{-1}$ was obtained. NUE and IWUE were $107.7 \mathrm{~kg} \mathrm{DM} \mathrm{ha}^{-1} \mathrm{~N}$ and $58 \mathrm{~kg} \mathrm{ha}^{-1} \mathrm{~mm}^{-1}$ or $5.8 \mathrm{~kg} \mathrm{~m}^{-3}$, respectively. Compared to previous studies and yields regarding silage corn, our DM yields were remarkably higher. This is an important finding for the feeding of animals, as well as sustainability of water and nitrogen use. Consequently, the lower amounts of irrigation water results in a significant decline in silage corn yield.

As a result, different fertigation techniques offer the possibility of maximizing NUE for corn silage. Thus, with an appropriate $\mathrm{N}$ frequency, $\mathrm{N}$ application should not exceed plant need and should be performed when the soil water is not leaching of the root zone. The results from this study could be very useful in the management of irrigation and nitrogen fertigation for silage corn.

\section{AKNOWLEDGEMENTS}

This study includes a part of the doctorate thesis (Ramazan YOLCU) and the research project (ZF2011026) carried out from 2011 to 2012 at the farm of Devegecidi Dam (Diyarbakir, Turkey). In addition, this research project was supported by the Çukurova University (Adana, Turkey), Scientific Research Projects Coordination Office.

\section{LITERATURES CITED}

Allen, M., S. Ford, J. Harrison, C. Hunt, J. Lauer, R. Muck and S. Soderlund. 1995. Corn silage production, management, and feeding. (eds. G. Roth and D. Undersander). American Society of Agronomy, NCR574, 42 pp.

Bouazzama, B., D. Xanthoulis, A. Bouaziz, P. Ruelle and J.C. Mailhol. 2012. Effect of water stress on growth, water consumption and yield of silage maize under flood irrigation in a semiarid climate of Tadla (Morocco). Biotechnologie, Agronomie, Société et Environment, 16 (4), 468-477

Bronson, K.F., J.D. Booker, J.P. Bordovsky, J.W. Keeling, T.A. Wheeler, R.K. Boman, M.N. Parajulee, E. Segarra and R.L. Nichols. 2006. Site-specific irrigation and nitrogen management for cotton production in the Southern High Plains. Agron. J. 98:212-219.

Burt, M.C. 1998. Fertigation Basics. Irrigation Training and Research Center (ITRC), ITRC Paper 98-001. California Polytechnic University, San Luis Obispo, CA, USA.

Cakir, R. 2004. Effects of water stress at different development stages on vegetative and reproductive growth of corn. Field Crop Res., 89(1):1-16.

Carpici, E.B., N. Celik and G. Bayram. 2010. Yield and quality of forage maize as influenced by plant density and nitrogen rate. Turkish Journal of Field Crops, 2010, 15(2): 128-132

Cetin, O and İ. Tolay. 2009. Fertigation. Hasad Publishing, ISBN: 978-975-8377-69-5, İstanbul, p. 160. (in Turkish)

Cetin, O. 1996. Irrigation water requirement of second crop corn under Harran Plain conditions. Rural Services Sanliurfa Research Institute Publications, No. 90, Sanliurfa, Turkey; $44 \mathrm{pp}$ (in Turkish)

Cetin, O. and L. Bilgel. 2002. Effects of different irrigation methods on shedding and yield of cotton. Agric Water Manage, Volume 54/1, 1-15.

Cetin, O., E.S. Koksal and A.F. Tar1. 2013. Basic approaches on water consumptive use and irrigation water requirement for drip irrigation. General Directorate of Agricultural Researchs and Politics, Head of Soil and Water Resources, Publication No: TAGEM-2013-22, Ankara, Turkey (in Turkish). 
Cigdem, I and F. Uzun. 2006. A study on some silage sorghum cultivars which can be cultivated as second crop at plains in Samsun. J Fac Agric OMU 21(1):14-19

DMI. 2014. Meteorological statistics. Turkish State Meteorological Service. Available at www.dmi.gov.tr (Accessed: 20 December 2014)

Duncan, W.G., D.L. Shaver and W.A. Williams. 1977. Sunlight and temperature effects on corn growth and yield. California Agriculture, August 1977, 13-14

Emile, J.C., M. Al-Rifai, X. Charrier, P. Leroy and Y. Barriere. 2006. Grain Sorghum Silages as an Alternative to Irrigated Maize Silage. In: Proceedings of the 21st general meeting of the european grassland federation, April 3-6, Badajoz, Spain

Fageria, N.K., V.C. Baligar and Y.C. Li. 2008. The role of nutrient efficient plants in improving crop yields in the twenty first century. Journal of Plant Nutrition, 31: 11211157

Fageria, N.K., V.C. Baligar and R.B. Clark. 2006. Physiology of Crop Production. New York: The Haworth Press

Garcia, S.Y. 2011. Growing maize for silage. Tech Note 5, p. 10. Available at www.futuredairy.com.au (Accessed: 19 December 2014)

Gencoglan, C and A. Yazar. 1999. The effects of deficit irrigations on corn yield and water use efficiency. Tr J Agric Forest 23:233-241

Gheysari, M., S.M. Mirlatifi, M. Bannayan, M. Homaee and G. Hoogenboom. 2009. Interaction of water and nitrogen on maize grown for silage. Agri. Wat. Man. 9 6, 809 - 821

Greenwood, K.L., G.N. Mundy and K.B. Kelly. 2008. On-farm measurement of the water use and productivity of maize. Aust J Exp Agric 48(3):274-284

Hagin, J,, M. Sneh and A. Lowengart-Aycicegi. 2002. Fertigation - Fertilization Through Irrigation. IPI Research Topics No. 23. Ed. by A.E. Johnston. International Potash Institute, Basel, Switzerland.

Hammad, H.M., A. Ahmad, F. Abbas and W. Farhad. 2012. Optimizing water and nitrogen use for maize production under semiarid conditions. Turk J Agric For., 36, 519-532

Hartz, T.K. and G.J. Hochmuth. 2005. Fertility management of drip-irrigated vegetables. Vegetable Research and Information Center, UC. Davis, USA, p. 6

Hassan, S.W., F.C. Oad, S.D. Tunio, A.W. Gandahi, M.H Siddiqui, S.M. Oad and A.W. Jagirani. 2010. Impact of nitrogen levels and application methods on agronomic, physiological and nutrient uptake traits of maize fodder. Pak J. Bot., 42(6): 4095-4101

Horneck, D.A. and R.O. Miller. 1998. Determination of Total Nitrogen in Plant Tissue. In: Kalra, Y.P. Ed: Handbook of reference methods for plant analysis. pp.75-83. CRC Press, New York.

Howell, T.A. 2006. Challenges in increasing water use efficiency in irrigated agriculture. The Proceedings of International Symposium on Water and Land Management For Sustainable Irrigated Agriculture. April 4-8, 2006, Adana, Turkey

Humphreys, L., B. Fawcett, C. O'Neill and W. Muirhead. 2005. Maize under drip, sprinkler and furrow irrigation. IREC Farmers' Newsletter. No. 170

Ibrikçi, H., A.C. Ülger, H.M. Sen, G. Buyuk, N. Guzel, B. Cakir and G. Ozgenturk. 2001. Optimization of nitrogen use for second crop corn growth under Cukurova conditions. Tarp Project No: 1951. Final Report, Adana, Turkey (in Turkish).

Kacar, B. 1984. Plant nutrition. Ankara University, Agricultural Faculty Publications, No: 899/250, Ankara (in Turksih).
Kafkafi, U. and J. Tarchitzky. 2011. Fertigation. A tool for efficient fertilizer and water management. International Fertilizer Industry Association (IFA), International Potash Institute (IPI), Paris, France.

Kang, S.Z. and J.H. Zhang. 2004. Controlled alternate partial root-zone irrigation: its physiological consequences and impact on water use efficiency. J. Exp. Bot. 55, 2437-2446.

Kara, S.M., M. Deveci, D. Özbay and N. Şekeroğlu. 1999. Effects of different amount of nitrogen and seed densities on fresh biomass and some quality parameters of corn silage. 3rd National Congress of Field Crops, 15-18 November, 1999, Adana, Turkey Vol. III. 172- 177. (in Turkish)

Karasahin, M., 2014. Effects of different irrigation methods and plant density on silage yield and yield components of PR 31 Y43 hybrid corn cultivar. Turk. J. Agric. For., 38: 159-168.

Kiziloglu, M.F., U. Sahin and T. Kuşlu. 2009. Determining water-yield relationship, water use effîciency, crop and pan coeffients for silage maize in a semiarid region. Irrigation Science, 27: 129-137.

Kolver, E.S., J.R. Roche1, D. Miller and R. Densley. 2001. Maize silage for dairy cows. Proceedings of the New Zealand Grassland Association 63: 195-201.

Lui, Y., J. Li and Y. Li. 2013. Nitrogen dynamics in soil and maize yield as affected by drip fertigation splits and rates in semi-humid region. The American Society of Agricultural and Biological Engineers. Annual International Meeting, 2124 July 2013, Kansas City, Missouri, USA, 747-757

Moll, R.H., E.J. Kamprath and W.A. Jackson. 1982. Analysis and interpretation of factors which contribute to efficiency to nitrogen utilization. Agron. J. 74:562-564

Morrow, M. and D.R. Krieg. 1990. Cotton management strategies for a short growing season environment: WaterNitrogen Considerations. Agron. J. 84 (1990): 52-56.

Musick, J.T., F.B. Pringle, W.L. Harman and B.A. Stewart. 1990 Long-term irrigation trends: Texas High Plains. App. Eng. Agric. 6:717-724.

Nafziger, E. 2011. The importance of sunlight. crop observation and recommendation network. Corn Newsletter. The Ohio State University. Ohio, USA.

Oktem, A. 2008. Effect of water shortage on yield, and protein and mineral compositions of drip irrigated sweet corn in sustainable agricultural systems. Agri. Water Manage. 95(9): 1003-1010

Oktem, A., M. Simsek and A.G. Oktem. 2003. Deficit irrigation effects on sweet corn (Zea mays saccharata Sturt) with drip irrigation system in a semi-arid region: I. Water-yield relationship. Agric. Water Manage. 61 (1), 63-74

Overman, A.R. and F.G. Martin. 2002. Corn response to irrigation and tillage. Commun Soil Sci Plant Anal 33(1920):3603-3608

Payero, J.O., D. Tarkalson, S. Irmak, D. Davison and J.L. Petersen. 2009. Effect of timing of a deficit-irrigation allocation on corn evapotranspiration, yield, water use efficiency and dry mass. Agric. Water Manage. 96: 13871397.

Payero, J.O., S.R. Melvin, S. Irmak and D. Tarkalson. 2006. Yield response of corn to deficit irrigation in a semiarid climate. Agric Water Manage. 84:101-112

Qasim, M., I. Ahmad and T. Ahmad. 2008. Optimizing fertigation frequency for rosa Hybrida L. Pak. J. Bot., 40(2): 533-545.

Rusere, F., G. Soropa, O. Svubure, S. Gwatibaya, D. Moyo, A. Ndeketeya and G.A. Mavima. 2012. Effects of deficit irrigation on winter silage maize production in Zimbabwe. International Research Journal of Plant Science, Vol. 3(9) pp. 188-192. 
Sade, B. 1987. Agronomic properties of some hybrid corn varieties under Çumra conditions. Selcuk University, Natural Science Institute, Thesis of M. Sci., Konya. (in Turkish).

Sade, B. and S. Soylu. 2008. Corn farming in the world and Turkey. National Corn Symposium, Konya, Turkey, pp. 101-108 (in Turkish).

Schmaler, K., U. Kruger and H. Richert. 2003. Ertrag und qualita"t von silomais in abha"ngigkeit vom wasserangebot. Arch Agron Soil Sci 49(4):357-374

Smith, R.E. and A.W. Warrick. 2007. Soil water relationships. In:Hoffman, G.J., Evans, R.G., Jensen, M.E., Martin, D.L., Elliott, R.L. (Eds.), Design and Operation of Farm Irrigation Systems. 2nd ed. ASABE, MI, pp. 120-160

Sne, M. 2006. Microirrigation in arid and semiarid regions, guidelines for planning and design. ICID, Holland.

Tisdale, S.L., W.L. Nelson, J.D. Beaton and J.L. Havlin. 1993. Soil fertility and fertilizers. Fifth edition. MacMillan Publishing Company. NY

TUIK. 2013. Statistics of crop production. Available at www.tuik.gov.tr (Accessed: 15 May 2014)

Turgut, I. 2002. Cultivation of corn silage. In: Açıkgöz, E., Turgut, I, Filya, I, (Eds). Growing Silage Crops. Hasad Pressing, Istanbul, Turkey, pp. 11-33 (in Turkish).
Witt, C., A. Dobermann, S. Abdulrachman, H.C. Gines, W. Guanghuo, R. Nagarajan, S. Satawathananont, T.T. Son, P.S. Tan, L.V. Tiem, G. Simbahan and D.C. Olk. 1999. Internal nutrient efficiencies in irrigated lowland rice of tropical and subtropical Asia. Field Crops Res. 63:113-138.

Yazar, A., F. Gökçel and M.S. Sezen. 2009. Corn yield response to partial rootzone drying and deficit irrigation strategies applied with drip system. Plant Soil Environ. 55 (11): 494 503

Yazar, A., M.S. Sezen and B. Gencel. 2002. Drip irrigation of corn in the Southeast Anatolia Project (GAP) area in Turkey. Irrig. Drain, 51: 293-300.

Yildirim, O. 2003. Design of irrigation systems. University of Ankara, Agricultural Faculty, Publication No: 1536, Lecture Books No : 489, Ankara, Turkey, 348 p. (in Turkish)

Young, D.R. and W.K. Smith. 1980. Influence of sunlight on photosynthesis, water relations, and leaf structure in the understory species Arnica Cordifolia. Ecology, Vol. 61, No 6 , $1380-1390$

Yurtsever, N. 2011. Experimental statistical methods. Soil, Fertilizer and Water Research Institute, Technical Pub. No.: 56, Pub. No.: 121, Ankara, (in Turkish) 